\title{
Influence of Morphology of Carbide Phase in Chromium Cast Iron on Wear Resistance
}

Malwina Dojka, Andrzej Studnicki

Silesian University of Technology, Foundry Department, Towarowa 7, 44-100 Gliwice, Poland.

E-mail: malwina.dojka@polsl.pl, andrzej.studnicki@polsl.pl

The article presents results of $\mathrm{M}_{7} \mathrm{C}_{3}$ carbides stereological parameters measurement and wear tests of chromium cast irons. There are two types of material were compared: not inoculated chromium cast iron and the same material about $4 \%$ addition of titanium by weight. The samples for studies were taken from casting formed by pouring into ATD-Is tester mould. Then they were properly prepared for testing. Stereological analysis was conducted in Image J software, where the following parameters of carbides was measured: area, width, length, perimeter, and circularity. Wear test was executed using pin-on-disk method on Tribotester 3-POD. Results of research shown that $\mathrm{Ti}$ addition results in formation of $\mathrm{TiC}$ carbide, which is an underlay for crystallization of $\mathrm{M}_{7} \mathrm{C}_{3}$ carbides. The effect of this was the finer grain of $\mathrm{M}_{7} \mathrm{C}_{3}$ and the lower weight losses during abrasion.

Keywords: Chromium Cast Iron, $\mathrm{M}_{7} \mathrm{C}_{3}$ Carbide, Stereological Parameters, Wear

\section{References}

[1] STUDNICKI, A. (2013). Role of selected inoculants in crystallization of wear resistant high chromium cast iron. PAN. Katowice - Gliwice.

[2] GROMCZYK, M., KONDRACKI, M., STUDNICKI, A., SZAJNAR, J. (2015). Stereological Analysis of Carbides in Hypoeutectic Chromium Cast Iron. In: Archives of Foundry Engineering, Vol. 15, Issue 2, pp. 17 - 22. PAN. Katowice - Gliwice.

[3] STUDNICKI, A., JEZIERSKI J. (2012). Stereological parameters of carbides in modified wear resistant Fe-CCr alloys. International Conference on Metallurgy and Materials 23 - 25 May 2012. Brno, Czech Republic, EU.

[4] STUDNICKI, A., DOJKA, R., GROMCZYK, M., KONDRACKI, M. (2016). Influence of Titanium on Crystallization and Wear Resistance of High Chromium Cast Iron. In: Archives of Foundry Engineering, Vol. 16, Issue 1, pp. 117 - 123. PAN. Katowice - Gliwice.

[5] NÁPRSTKOVÁ, N., CAIS, J., STANČEKOVÁ, D. (2014). Influence of Alsi7Mg0.3 Alloy Modification by Sb on the Tool Wear. In: Manufacturing Technology, Vol. 14, No. 1, pp. 75 - 79.

[6] KOPYCIŃSKI, D., GUZIK, E., SIEKANIEC, D., SZCZESNY, A. (2015). The Effect of Addition of Titanium on The Structure and Properties of High Chromium Cast Iron. In: Archives of Foundry Engineering, Vol. 15, Issue 3, pp. 35 - 38. PAN. Katowice - Gliwice.

[7] MIRZAEE, M., MOMENI, A., KESHMIRI, H., RAZAVINEJAD, R. (2014). Effect of Titanium and Niobium on Modifying the Microstructureof Cast K100 Tool Steel. The Minerals, Metals \& Materials Society and ASM International 2014.

[8] ZHANG, Q., LIU, Q., SHIBATA, H., WANG, Q., JÖNSSON, P., HE, J., NAKAJIMA, K. (2014). Partial Equilibrium Prediction of Solidification and Carbide Precipitation in Ti-added High Cr Cast Irons. In: ISIJ International, Vol. 54 (2014), No. 2. 